\title{
GROWTH BEHAVIOR AND PRODUCTIVITY OF LEMONGRASS (CYMBOPOGON CITRATUS) AS AFFECTED BY FOLIAR APPLICATIONS OF VARIOUS PROMOTING
}

\author{
M.M. Moussa \\ Horticulture Dept., Fac. of Agric., Menoufia Univ., Shebin El-Kom, Egypt. \\ Received: Feb. 10, 2019 \\ Accepted: Feb. 14, 2019
}

\begin{abstract}
This work was performed during two successive growth seasons (2013 and 2014) at the Experimental Farm, Faculty of Agriculture, Menoufia University, Shebin EI - Kom , Egypt to study the individual and combined effects of foliar application of benzyl adenine $(B A)$ at $(0,50$ and $100 \mathrm{mg} / \mathrm{l})$ and mixture of some micronutrients (iron, manganese, zinc and boron) as a compound chelated (EDTA form) at different levels on growth, yield and active constituents of lemongrass plant (Cymbopogon citratus L.) grown on a clayey soil. Micronutrients were sprayed at different concentrations, i.e., MO = irrigation water without any of micronutrients, $M 1=100,50,50$ and $25 \mathrm{mg} / \mathrm{l}, \mathrm{M2}=150,100$, 100 and $50 \mathrm{mg} / \mathrm{l}, \mathrm{M3}=200,150,150$ and $75 \mathrm{mg} / \mathrm{l}$ for Fe, Mn, Zn and B, respectively. The experiment was carried out in a split plot design with three replicates.
\end{abstract}

Results indicated that, the combinations between different rates of $B A$ and mixture of micronutrients had a significant improvement effect on growth and yield characters in most cases expressed as plant height (cm), number of tillers/plant, fresh and dry weights of herb (g/plant) and fresh weight of herb (ton/fed) in the $1^{\text {st }}$ and $2^{\text {nd }}$ cuts during the two seasons. Their highest values were obtained in the plants treated with BA at $100 \mathrm{mg} / \mathrm{l}$ combined with M2 level of micronutrients in the two cuts through the first and second seasons. The highest oil percentages were obtained by using BA at $50 \mathrm{mg} / \mathrm{l}+\mathrm{M2}$ level of micronutrients and BA at $100 \mathrm{mg} / \mathrm{l}+\mathrm{M1}$ level of micronutrients for the first and second cuts respectively during the two seasons. Citral a (geranial), citral b (neral) and myrcene were found to be the major compounds in the essential oil of Cymbopogon citrates which reached its maximum values by using $B A$ at $100 \mathrm{mg} / \mathrm{l}+\mathrm{M1}$ level of micronutrients, $B A$ at $50 \mathrm{mg} / \mathrm{l}+\mathrm{M} 2$ level of micronutrients and M1 level of micronutrients without using $B A$ respectively, during the $2^{\text {nd }}$ cut in the first season.

Key words: Lemongrass, Benzyl adenine, Micronutrients (Fe, Mn, Zn and B), Vegetative growth parameters and Chemical compositions.

\section{INTRODUCTION}

The Egyptian government needs to increase the production of medicinal and aromatic plants in order to cover the extending demands of local markets and exportation. One of the most important medicinal and aromatic plants is lemongrass (Cymbopogon citratus) which belongs to genus Cymbopogon, family poaceae (Graminaceae). It is a perennial herb widely cultivated in the tropics and subtropics regions around the world. The propagation of lemongrass carried out by using plant division. Cymbopogon citratus contains 0.2 to $1.5 \%$ volatile oil on a dry basis with widely variation of the chemical composition as a function of habitat genetic diversity and different agronomic treatment of the culture (Carlson et al., 2001). The volatile oil is described by a high content of citral A (geranial) and citral $B$ (neral) which is used as a raw material for the production of ionone, vitamin $A$ and beta carotene (Paviani et al., 2006) and represented about $80 \%$ of 
the essential oil (Aziz and El-Ashry, 2002; Aziz et al., 2010 and Koffil et al., 2009). As a medicinal herb, lemongrass has been considered as anti-oxidant (Dorman et al., 2000), carminative, antimicrobial (Horne et al., 2001), acts as central nervous system depressant, has antifungal and antibacterial activity (Chao and Young, 2000). Also the essential oil which extracted from fresh leaves is used for its analgesic spasmolytic, antipyretic, anti-inflammatory, diuretic and tranquilizing properties in treating various digestive disorders, diabetes, inflammation, nervous disorders and fever (Onawunmi et al., 1984 and Negrelle and Gomes, 2007).

Benzyl adenine (BA) is an important plant hormone that regulates different processes of plant growth and physiological responses including cell division and differentiation, enhancement of leaf expansion and nutrient mobilization in high values to increase the yield (Davies, 1995). In this respect, evidence suggests that (BA) belongs to a group of plant hormones named cytokinines and its role is connected with the growth and development of plants. It is also implicated in the vascular development and synthesis of secondary metabolites such as alkaloids, anthocyanins and indols. It influences chlorophyll biosynthesis and chloroplast differentiation by stimulation of 5aminolevulinc acid synthesis (Duszka et al., 2009). When exogenously applied, BA has been shown to result in increasing plant height (Letham, 1969), leaf area (Abdullah et al., 1986), branching (Hrotko et al.,1996).

Micronutrient deficiency is widespread in plants, animals and humans, especially in many arid countries due to the calcareous nature of soils, high $\mathrm{pH}$, low organic matter, salt stress, continual drought, high bicarbonate content in irrigation water and/or imbalanced application of fertilizers (Malakouti, 2008). However, micronutrient deficiencies can result in great deal of limitation in the physiological and metabolic processes even if the plants need only small amount of micronutrient for satisfactory crop growth and production (Nasiri et al., 2010). Micronutrient elements like manganese $(\mathrm{Mn})$, boron $(\mathrm{B})$, zinc $(\mathrm{Zn})$ and iron (Fe) play a major role in enhancement agricultural production and quality (Gomaa et al., 1986). Iron (Fe) deficiency impairs many plant physiological processes because it is involved in chlorophyll and protein synthesis (Fahad et al., 2014). Boron (B) encourages the stability and rigidity of cell wall structure and subsequently, supports shape and strength of the plant cell (Brown et al., 2002). Zinc ( $\mathrm{Zn}$ ) is an essential micronutrient for sugar regulation and assorted enzymatic activity associated with plant growth, carbonic anhydrase activity, synthesis of chlorophyll and uptake of nitrogen and protein quality (Cakmak, 2008; Khosa et al., 2011 and Fahad et al., 2014). Manganese (Mn) plays an important roles in photosynthesis (Mousavi et al., 2011) and also serves as electron storage and delivery to the chlorophyll reaction centers (Millaleo et al., 2010).

\section{MATERIALS AND METHODS}

The present work was conducted in two successive growth seasons (2013 and 2014 ) at the Experimental Farm, Faculty of Agriculture, Menoufia University, Shebin El - Kom , Egypt $\left(30.52^{\circ} \mathrm{N}\right.$ and $\left.30.99^{\circ} \mathrm{E}\right)$, to study the individual and combined effects of foliar application of benzyl adenine (BA) at ( 0 , 50 and $100 \mathrm{mg} / \mathrm{l})$ and mixture of some micronutrients (iron, manganese, zinc and boron) as a compound chelated (EDTA form) at different concentrations on growth, yield and active constituents 
of lemongrass plant (Cymbopogon citratus L.) grown on a clayey soil.

Representative surface soil samples $(0-30 \mathrm{~cm})$ were taken from the used soil before performance of the experiment. Soil samples were air - dried, ground, mixed well, sieved through a $2 \mathrm{~mm}$ sieve. The samples then were analyzed for determination of some physical and chemical properties. Also, the contents of some available macro - and micronutrients were described according to the methods by Cottenie et al. (1982); Page et al. (1982) and Kim (1996). The obtained data were recorded in Table (1).

The experiment was carried out in a split plot design with three replicates. The experimental plots were 36 units (12 treatments $\times 3$ replicates) and the area of each plot was $4 \mathrm{~m}^{2}(2 \mathrm{~m}$ length $\times 2 \mathrm{~m}$ width) including four ridges. Before transplanting, at final soil preparation, all plots were fertilized by ordinary super phosphate $\left(15.5 \% \mathrm{P}_{2} \mathrm{O}_{5}\right)$ at rate of 200 $\mathrm{kg} / \mathrm{fed}$. $+50 \mathrm{~kg} \mathrm{/} \mathrm{fed.} \mathrm{of} \mathrm{agricultural}$ sulphur $+25 \mathrm{~m}^{3} / \mathrm{fed}$. of mature compost. Also, the experimental plots were divided into three main groups (12 plots / main group), which treated with one rate of benzyl adenine (BA) $(0,50$ and $100 \mathrm{mg} / \mathrm{l})$. The sub main plots were treated with mixture of some micronutrients (iron, manganese, zinc and boron) as a compound chelated (EDTA form), i.e., M0 $=$ irrigation water without any of micronutrients, $M 1=100,50,50$ and 25 $\mathrm{mg} / \mathrm{l}, \mathrm{M} 2=150,100,100$ and $50 \mathrm{mg} / \mathrm{l}, \mathrm{M} 3=$ 200, 150, 150 and $75 \mathrm{mg} / \mathrm{l}$ for Fe, Mn, Zn and $B$, respectively. Foliar application of micronutrients was done after three weeks of transplanted and repeated monthly in the early morning till the end of the experiment while, BA was sprayed twice at 14 days after transplanting and 10 days after harvesting the $1^{\text {st }}$ cut through the first and second seasons.

Table (1): Some physical and chemical properties of the used soil.

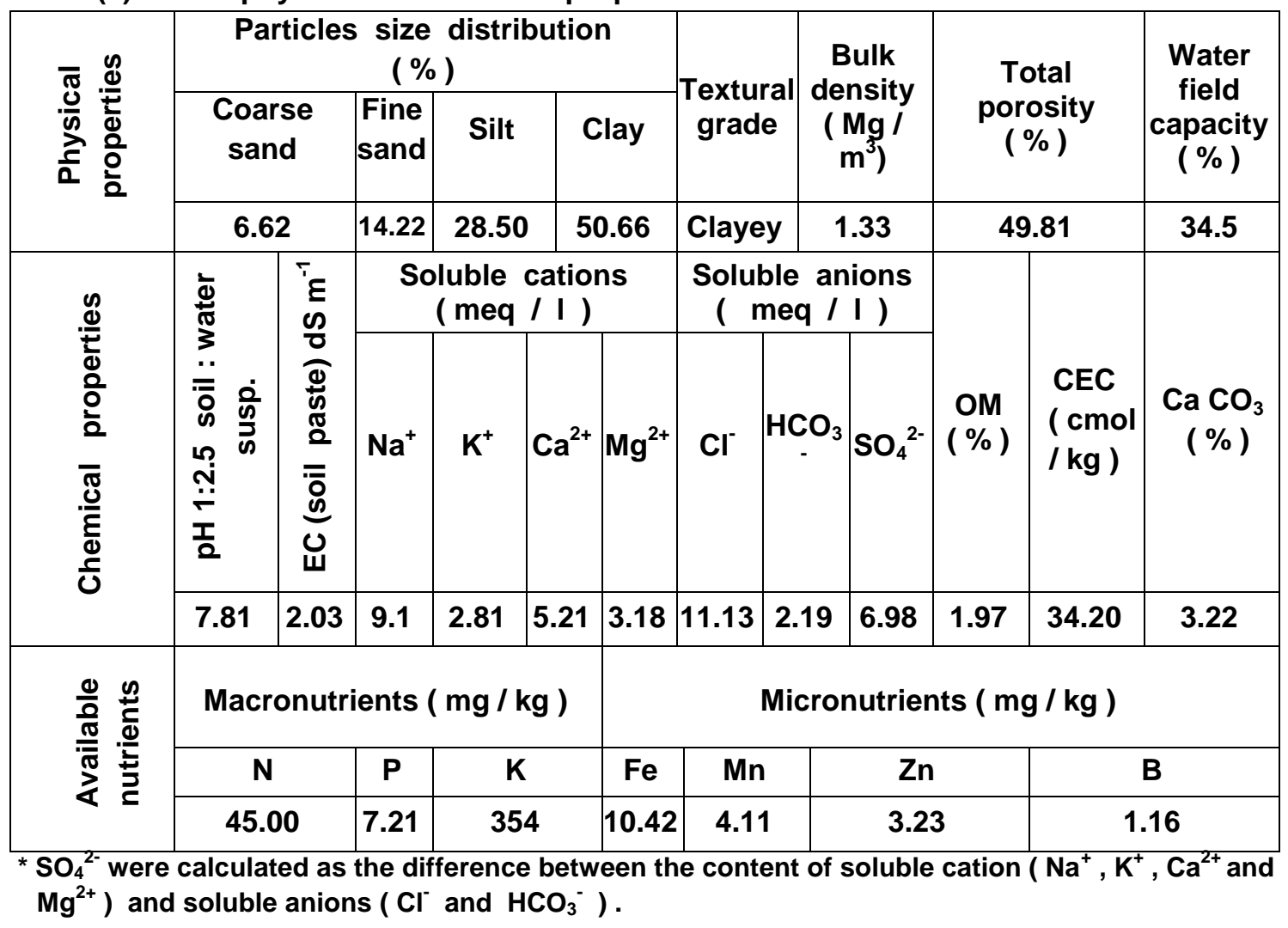


Uniform plants of lemongrass $(15 \mathrm{~cm}$ in height) were secured from Medicinal and Aromatic Plants Res. Dept., Hort. Res. Inst., Agricultural Research Centre, Ministry of Agriculture, Giza, Egypt and were transplanted on the first of March during two growing seasons, 2013 and 2014. The plants were transplanted to the Experimental Farm at a distance of $50 \mathrm{~cm}$ between the plants. All agricultural practices beginning from transplanting to harvesting were performed as recommended by Egyptian Ministry of Agriculture.

The plant samples were harvested (cutting) twice after 6 and 9 months from transplanting in each season and leaving about $15 \mathrm{~cm}$ above the soil surface. In each cut, plant samples were taken carefully from each replicate to estimate the following parameters:

\section{1- Vegetative growth characters}

Plant height (cm), number of tillers/plant, fresh and dry weights of herb ( $\mathrm{g} / \mathrm{plant}$ ) and fresh weight of herb and (ton/fed.). A portion of each herb sample was air - dried, oven - dried at 70 ${ }^{\circ} \mathrm{C}$ for $72 \mathrm{hrs}$. and dry weights were measured as (g/plant).

\section{2- Chemical constituents}

Photosynthetic pigments (chlorophyll a, b and carotenoids) were determined in fresh leaves $(\mathrm{mg} / \mathrm{g}$ fresh weight) as the methods described by Witham et al. (1971).

Essential oil percentages were determined in the fresh herb through the $1^{\text {st }}$ and $2^{\text {nd }}$ cuts in both seasons as described by British (1963).

The volatile oil obtained from the fresh leaves in the $2^{\text {nd }}$ cut during the first season was analyzed by using GLC Model HP-5890 with flame ionization detector that was fitted with capillary column, coated with carbowax 20M. The operating conditions were injector temperature $190{ }^{\circ} \mathrm{C}$, detector temperature $110{ }^{\circ} \mathrm{C}$, linear temperature programmed at $5{ }^{\circ} \mathrm{C} \mathrm{min}$, to $175{ }^{\circ} \mathrm{C} \mathrm{min}$, nitrogen (carrier gas) flow $2 \mathrm{ml} / \mathrm{min}$, hydrogen 30 $\mathrm{ml} / \mathrm{min}$, air $330 \mathrm{ml} / \mathrm{min}$. The peaks were recorded and the areas were determined by using HP-integrator. Oil components were identified by comparing the relation times of the authentic compound.

Plant samples were washed several times with a tap-water and then two times with distilled water, air-dried, oven-dried at $70^{\circ} \mathrm{C}$ for 48 hour, ground separately to a fine powder in a stainless grinder and stored in plastic bags until analysis. Total carbohydrate (\%) in the dried herb of lemongrass plants was determined using the colorimetric method described by Dubois et al. (1956). A half $\mathrm{g}$ portion of each dried plant sample was digested by $5 \mathrm{ml}$ of concentrated mixture of $\mathrm{H}_{2} \mathrm{SO}_{4}+$ $\mathrm{HClO}_{4}$ at (5: 0.5 ratio) according to Chapman and Pratt (1982). The content (\%) of $\mathrm{N}, \mathrm{P}$ and $\mathrm{K}$ were determined as described by Cottenie et al. (1982).

\section{Statistical analysis}

The obtained data of growth parameters were exposed to proper statistical analyses of variance (ANOVA) by using Minitab computer program and least significant difference (L.S.D.) which was calculated at level of $5 \%$ (Barbara and Brain, 1994).

\section{RESULTS AND DISCUSSION}

Effect of foliar application of benzyl adenine (BA) and mixture of micronutrients ( $\mathrm{Fe}, \mathrm{Mn}, \mathrm{Zn}$ and $\mathrm{B}$ ) either individually or in combination on:

\section{1-Growth and yield characters}

Data recorded in Table (2) explain that, growth and yield parameters of lemongrass plants expressed as plant height (cm), number of tillers/plant, fresh 
and dry weights of herb ( $\mathrm{g} / \mathrm{plant})$ and fresh weight of herb (ton/fed) were significantly increased by the application of both benzyl adenine (BA) concentrations in most cases, with superiority for $100 \mathrm{mg} / \mathrm{l} \mathrm{BA}$ was sprayed as compared to the control in two cuts during the first and second seasons. The increment in the studied growth parameters could be explained through the role of BA in stimulating xylem differentiation and vascular strand development, consequently more absorption of water and essential macro and micronutrients from the soil, which was reflected in more growth, as mentioned by (Sorokin and Thimann, 1964). In this connection, the obtained results have been supported by Mazrou (1992) on Datura innoxia and Eraki (1994) on Hibiscus sabdariffa. They found that, foliar application of BA significantly increased plant height, number of branches/plant as well as fresh and dry weights of whole plant than the control.

As for the effect of mixture micronutrients, data in Table (2) reveal that, different levels of micronutrients (M1, M2 and M3) statistically increased growth and yield parameters as compared to the control (MO) in most cases. The highest values of these traits were obtained in the plants sprayed by moderate level (M2) of micronutrients. Enhancing growth characters in response to the foliar application of micronutrients may be due to their positive action on increasing cell division in the meristematic tissues and accelerating carbohydrates and proteins formation (Ghanta and Mitra, 1993). Also, these elements play an important role in the multi-biological processes such as the role of $\mathrm{Zn}$ in the synthesis of IAA (Nijjar, 1985).The obtained results concerning the positive effect of using mixture of micronutrients $(\mathrm{Zn}, \mathrm{Mn}, \mathrm{Fe}$ and B) on some vegetative growth parameters of lemongrass plants go in line with the findings of Younis et al. (2013), who reported that, using micronutrients increased the growth and the quality of Rosa hybrida. Also Yadegari (2015) found that, the application of micronutrients increase the growth of Borago officinalis, Thymus vulgaris and Tagetes erecta.

Referring to the interactions effect between different foliar applications of BA and micronutrients, data in Table (2) illustrate that, growth and yield parameters of lemongrass were increased due to all tested combinations as compared to the control in the two cuts during both seasons. However, the combined treatment between BA at $\mathbf{1 0 0}$ $\mathrm{mg} / \mathrm{l}$ and micronutrients at M2 level induced the highest values in this concern during the $1^{\text {st }}$ and $2^{\text {nd }}$ cuts through two seasons. These results are in quite agreement with the finding of Eid et al. (2010) on tuberose plants

\section{2-Essential oil production.}

It was noticed from Table (3) that, all tested BA treatments increased essential oil production such as oil content (\%), oil yield (cc/plant) and oil yield (l/fed), particularly at high application rate (100 $\mathrm{mg} / \mathrm{BA}$ ) in the two cuts during both seasons exception of essential oil content (\%) in the first cut through the first season which reached its maxima by using BA at the lowest concentration. This improvement impact might be attributed to increased capacity of meristematic cells to build active substrate necessary for biosynthesis of essential oils (Mok and Mok, 2001). The influence of cytokinins on the biosynthesis and accumulation of volatile oil were studied by many researchers. Youssef et al. (2004) reported that, foliar application of kinetin on matthiola plant significantly promoted the growth and gave the highest oil percentage. 


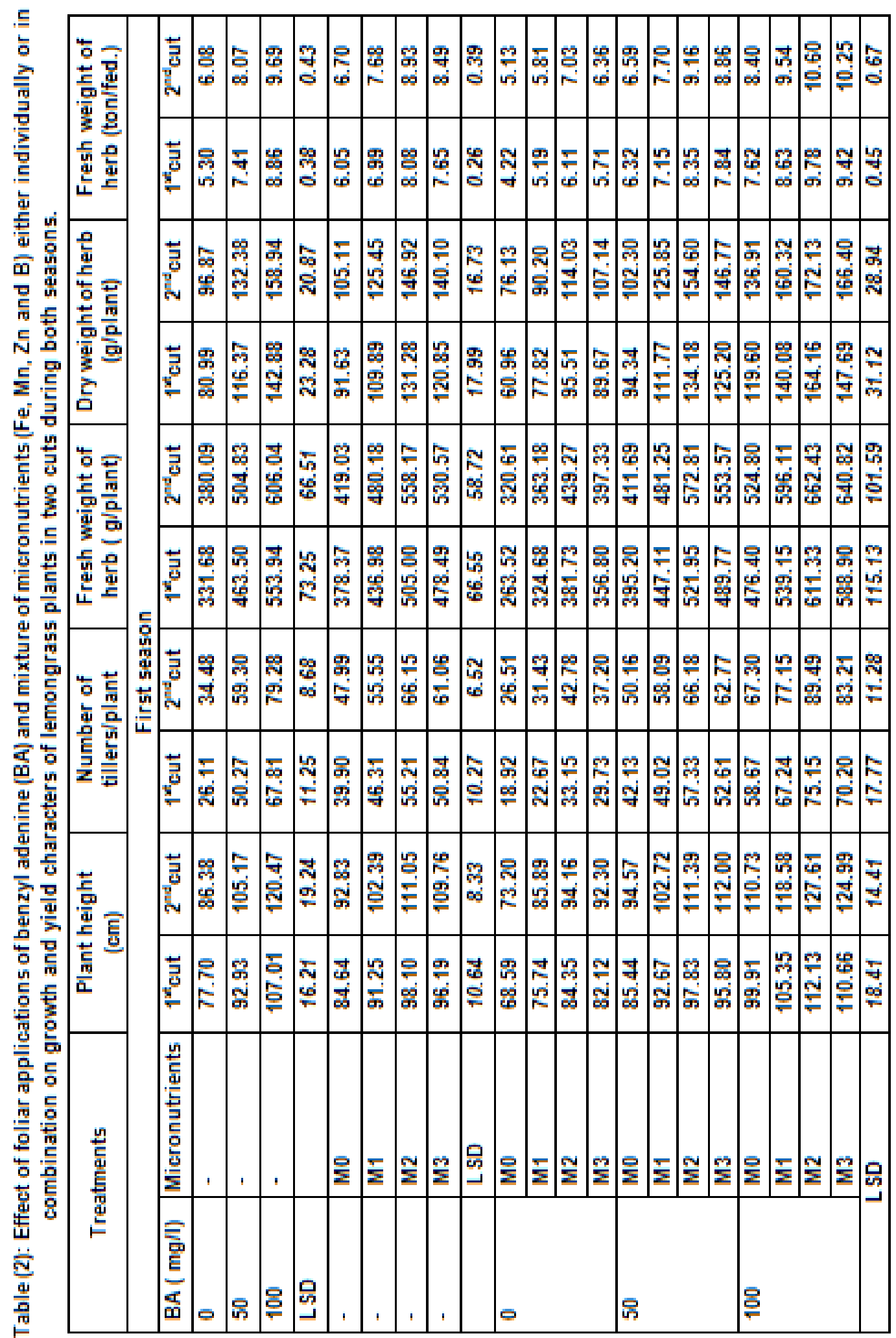




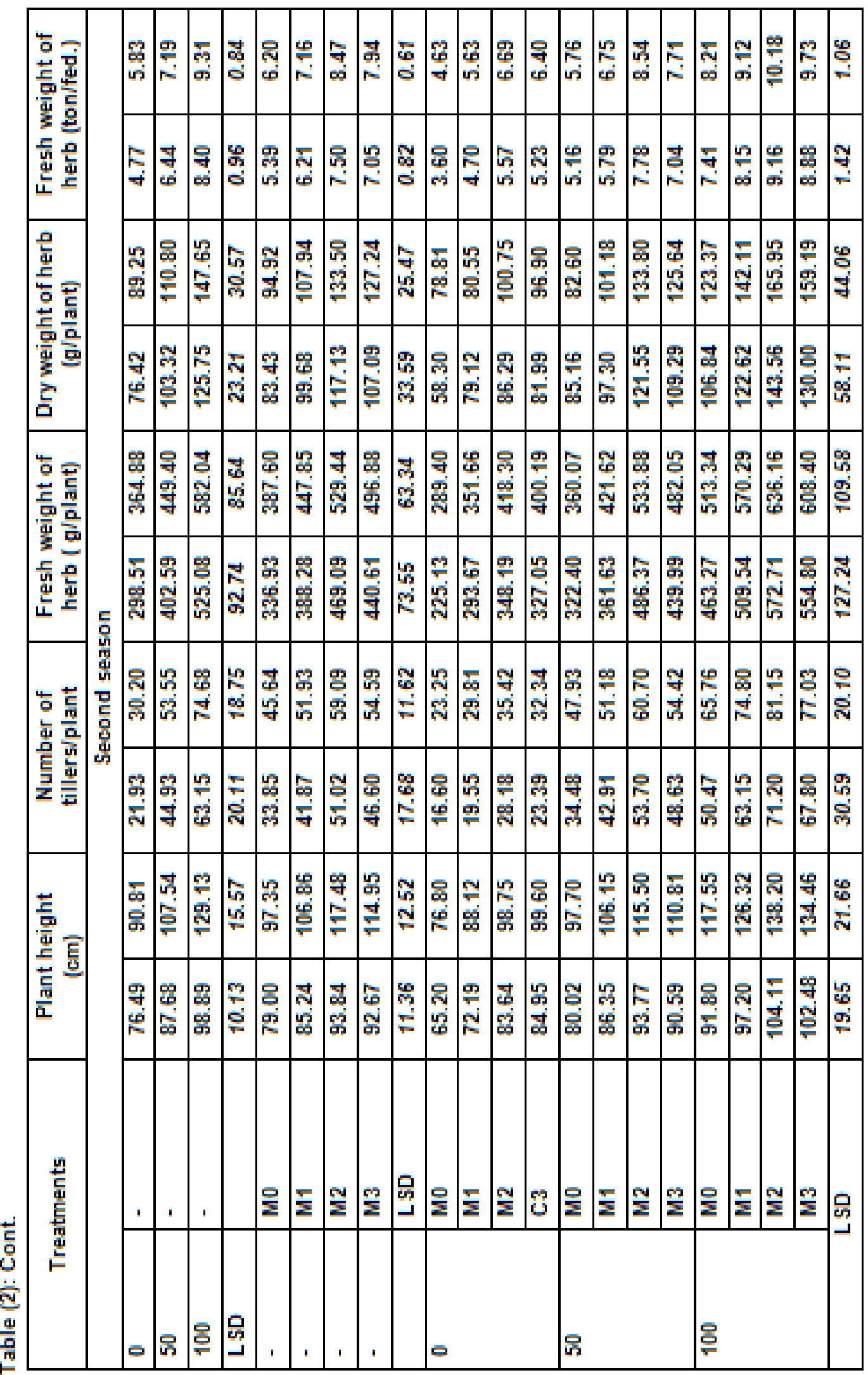


Table (3): Effect of foliar applications of benzyl adenine (BA) and mixture of micronutrients ( $\mathrm{Fe}, \mathrm{Mn}, \mathrm{Zn}$ and $\mathrm{B}$ ) either individually or in combination on essential oil production of lemongrass plants in two cuts during both seasons.

\begin{tabular}{|c|c|c|c|c|c|c|c|}
\hline \multicolumn{2}{|c|}{ Treatments } & \multicolumn{2}{|c|}{ Oil (\%) } & \multicolumn{2}{|c|}{ Oil yield (cc/plant) } & \multicolumn{2}{|c|}{ Oil yield $(\mathrm{l} / \mathrm{fed})$} \\
\hline \multicolumn{8}{|c|}{ First season } \\
\hline BA ( $\mathrm{mg} / \mathrm{l})$ & Micronutrients & $1^{\text {st }}$ cut & $2^{\text {nd }}$ cut & $1^{\text {st }}$ cut & $2^{\text {nd }}$ cut & $1^{\text {st }}$ cut & $2^{\text {nd }}$ cut \\
\hline 0 & - & 0.32 & 0.41 & 1.10 & 1.59 & 17.61 & 25.56 \\
\hline 50 & - & 0.42 & 0.51 & 1.97 & 2.63 & 31.49 & 42.04 \\
\hline 100 & - & 0.35 & 0.55 & 1.99 & 3.35 & 31.90 & 53.68 \\
\hline LSD & & NS & 0.09 & 0.36 & 1.05 & 8.64 & 10.58 \\
\hline- & MO & 0.30 & 0.42 & 1.15 & 1.78 & 18.46 & 28.57 \\
\hline- & M1 & 0.34 & 0.54 & 1.51 & 2.71 & 24.10 & 43.42 \\
\hline- & M2 & 0.44 & 0.55 & 2.24 & 3.13 & 35.92 & 50.08 \\
\hline \multirow[t]{2}{*}{-} & M3 & 0.38 & 0.46 & 1.84 & 2.48 & 29.51 & 39.64 \\
\hline & LSD & NS & 0.10 & 0.32 & 1.62 & 11.68 & 19.85 \\
\hline \multirow[t]{4}{*}{0} & MO & 0.25 & 0.35 & 0.66 & 1.12 & 10.55 & 17.96 \\
\hline & M1 & 0.31 & 0.42 & 1.01 & 1.53 & 16.09 & 24.40 \\
\hline & M2 & 0.39 & 0.49 & 1.49 & 2.15 & 23.83 & 34.45 \\
\hline & M3 & 0.35 & 0.40 & 1.25 & 1.59 & 19.99 & 25.44 \\
\hline \multirow[t]{4}{*}{50} & MO & 0.36 & 0.48 & 1.42 & 1.98 & 22.75 & 31.63 \\
\hline & M1 & 0.40 & 0.52 & 1.79 & 2.50 & 28.60 & 40.04 \\
\hline & M2 & 0.49 & 0.57 & 2.56 & 3.27 & 40.92 & 52.21 \\
\hline & M3 & 0.43 & 0.50 & 2.11 & 2.77 & 33.71 & 44.30 \\
\hline \multirow[t]{4}{*}{100} & MO & 0.29 & 0.43 & 1.38 & 2.26 & 22.10 & 36.12 \\
\hline & M1 & 0.32 & 0.69 & 1.73 & 4.11 & 27.62 & 65.83 \\
\hline & M2 & 0.44 & 0.60 & 2.69 & 3.97 & 43.03 & 63.60 \\
\hline & M3 & 0.37 & 0.48 & 2.18 & 3.08 & 34.85 & 49.20 \\
\hline \multicolumn{2}{|l|}{ LSD } & NS & 0.17 & 0.55 & 2.80 & 20.21 & 34.34 \\
\hline \multicolumn{8}{|c|}{ Second season } \\
\hline 0 & - & 0.47 & 0.36 & 1.47 & 1.35 & 22.78 & 21.66 \\
\hline 50 & - & 0.63 & 0.47 & 2.56 & 2.14 & 41.08 & 34.31 \\
\hline 100 & - & 0.63 & 0.51 & 3.32 & 2.98 & 53.09 & 47.82 \\
\hline LSD & & 0.12 & 0.15 & 1.08 & 1.12 & 16.25 & 14.88 \\
\hline- & MO & 0.52 & 0.42 & 1.83 & 1.72 & 29.29 & 27.61 \\
\hline- & M1 & 0.57 & 0.47 & 2.27 & 2.19 & 36.40 & 35.07 \\
\hline- & M2 & 0.62 & 0.47 & 3.04 & 2.54 & 47.75 & 40.68 \\
\hline \multirow[t]{2}{*}{-} & M3 & 0.59 & 0.44 & 2.65 & 2.18 & 42.50 & 35.03 \\
\hline & LSD & 0.08 & $N S$ & 1.35 & 0.61 & 11.39 & 13.67 \\
\hline \multirow[t]{4}{*}{0} & MO & 0.43 & 0.27 & 0.97 & 0.78 & 15.48 & 12.50 \\
\hline & M1 & 0.45 & 0.33 & 1.32 & 1.16 & 21.15 & 18.58 \\
\hline & M2 & 0.50 & 0.41 & 1.92 & 1.72 & 27.85 & 27.43 \\
\hline & M3 & 0.51 & 0.44 & 1.67 & 1.76 & 26.67 & 28.16 \\
\hline \multirow[t]{4}{*}{50} & MO & 0.57 & 0.48 & 1.84 & 1.73 & 29.41 & 27.65 \\
\hline & M1 & 0.62 & 0.50 & 2.24 & 2.11 & 35.89 & 33.75 \\
\hline & M2 & 0.73 & 0.50 & 3.55 & 2.67 & 56.79 & 42.70 \\
\hline & M3 & 0.60 & 0.43 & 2.64 & 2.07 & 42.24 & 33.15 \\
\hline \multirow[t]{5}{*}{100} & MO & 0.58 & 0.52 & 2.69 & 2.67 & 42.98 & 42.69 \\
\hline & M1 & 0.64 & 0.58 & 3.26 & 3.31 & 52.16 & 52.90 \\
\hline & M2 & 0.64 & 0.51 & 3.67 & 3.24 & 58.62 & 51.92 \\
\hline & M3 & 0.66 & 0.45 & 3.66 & 2.73 & 58.61 & 43.79 \\
\hline & LSD & 0.14 & 0.32 & 2.34 & 1.06 & 19.70 & 23.65 \\
\hline
\end{tabular}


Also El-Quesni et al. (2007) showed that, spraying kinetin produced the highest seed oil content of Cupressus sempervirens.

Additionally, the three levels of sprayed micronutrients exhibited highly increments in these values of oil production, especially the treatment of M2 level when compared with untreated plants (control) in $1^{\text {st }}$ and $2^{\text {nd }}$ cuts through two seasons. Many investigators reported that, micronutrient elements can lead to increase oil percentage (Yari et al., 2004 and Ravi et al., 2008) due to the enzymatic activity enhancement and increasing photosynthesis (Heidarian et al., 2011). As the volatile oil is secondary output of photosynthesis, so increasing microelements lead to increase the volatile oil content. Also, similar effect of micronutrients supply on these parameters were also reported by Nasiri et al. (2010) on Matricaria chamomilla and Eid et al. (2010) on Polianthes tuberose.

Regarding the interaction effect between foliar applications of BA and micronutrients in both growing seasons, data in Table (3) reveal that, the highest record for essential oil percentage was found in plants sprayed by BA at $50 \mathrm{mg} / \mathrm{l}$ plus M2 level of micronutrients in $1^{\text {st }}$ cut during two seasons while the application of BA at $100 \mathrm{mg} / \mathrm{l} \mathrm{combined} \mathrm{with} \mathrm{M1} \mathrm{level}$ of micronutrients induced the greatest enhancement in the essential oil percentage through the $2^{\text {nd }}$ cut during two seasons. Also the highest oil yield (cc/plant or $\mathrm{l} / \mathrm{fed}$ ) was registered by spraying BA at $100 \mathrm{mg} / \mathrm{l}+$ each of M2 or M1 level of micronutrients for the first and second cuts respectively, during two seasons. These results are similar to those obtained by Eid et al. (2010) on tuberose plants which reported that, both $\mathrm{Zn}$ an BA increased essential oil percentage compared to untreated plants.

\section{3-Macronutrients ( $N, P$ and $K$ ) and total carbohydrate percentages}

The effect of foliar application with BA at both concentrations on the content (\%) of macronutrients ( $N, P$ and $K$ ) as well as the content (\%) of total carbohydrate were reviewed in Table (4). These contents were increased with all BA treatments however, the highest values of $\mathbf{N}$ and $\mathbf{P} \%$ were scored by using low BA concentration, while the high concentration of BA produced the highest $\mathrm{K}$ and total carbohydrate content $(\%)$ in the dried herb through $1^{\text {st }}$ and $2^{\text {nd }}$ cuts in two seasons compared to the control. These results could be explained through the role of BA in increasing the width of conductive tissues (xylem and phloem) and consequently increasing the absorption and translocation of the elements necessary for plant growth (Krishnamoorthy, 1981). This again suggests, the influence of BA on the mechanism of ions uptake may be related to its effect on membrane permeability and rate of ion entry through the membrane or enhance their translocation to the shoot (Van-Steveninck, 1976). Furthermore, kinetin altered membrane composition (Merillon et al., 1993), its selectivity (Dhakal and Erdei,1986) and increased membrane fluidity (Vodanik et al., 1999). These results pointed in the same direction of Abd El-Aziz (2007) and Eid and Abou-Leila (2006) on croton plants.

Also, data in Table (4) revealed strong improvement in plant content (\%) of $\mathbf{N}, \mathbf{P}$, $K$ and total carbohydrate under the applying of micronutrients as foliar application. The greatest increments in the content (\%) of $\mathrm{K}, \mathrm{P}$ and $\mathrm{N}$ were done by the application of micronutrients at M1, M2 and M3 levels respectively, compared to the control. Also spraying plants by M3 level produced the highest total content $(\%)$ of carbohydrate in the two seasons with the exception of $2^{\text {nd }}$ cut 
Table (4): Effect of foliar applications of benzyl adenine (BA) and mixture of micronutrients ( $\mathrm{Fe}, \mathrm{Mn}, \mathrm{Zn}$ and $\mathrm{B}$ ) either individually or in combination on some macronutrients ( $N, P$ and $K$ ) and total carbohydrate content (\%) of lemongrass plants in two cuts during both seasons.

\begin{tabular}{|c|c|c|c|c|c|c|c|c|c|}
\hline \multicolumn{2}{|c|}{ Treatments } & \multicolumn{2}{|c|}{ N (\%) } & \multicolumn{2}{|c|}{$\mathbf{P}(\%)$} & \multicolumn{2}{|c|}{ K (\%) } & \multicolumn{2}{|c|}{\begin{tabular}{|c|} 
Total \\
carbohydrate (\%)
\end{tabular}} \\
\hline \multicolumn{10}{|c|}{ First season } \\
\hline \multicolumn{2}{|c|}{ BA(mg/l)Micronutrients } & $1^{\text {st cut }}$ & $2^{\text {nd }}$ cut & $1^{\text {st }}$ cut & $2^{\text {nd }}$ cut & $1^{\text {st }}$ cut & $2^{\text {nd }}$ cut & $1^{\text {st }}$ cut & $2^{\text {nd }}$ cut \\
\hline 0 & \begin{tabular}{l|l}
- &
\end{tabular} & 0.98 & 1.08 & 0.29 & 0.26 & 2.01 & 1.81 & 13.30 & 12.50 \\
\hline 50 & - & 1.41 & 1.28 & 0.49 & 0.43 & 2.34 & 2.04 & 16.11 & 14.70 \\
\hline 100 & - & 1.22 & 1.23 & 0.42 & 0.40 & 2.78 & 2.36 & 17.55 & 15.58 \\
\hline LSD & & 0.21 & 0.13 & 0.17 & 0.13 & 0.26 & 0.31 & 1.65 & 2.06 \\
\hline- & MO & 1.09 & 1.14 & 0.34 & 0.30 & 2.21 & 1.96 & 14.77 & 13.42 \\
\hline- & M1 & 1.14 & 1.15 & 0.39 & 0.35 & 2.50 & 2.18 & 15.38 & 14.01 \\
\hline- & M2 & 1.26 & 1.23 & 0.46 & 0.41 & 2.44 & 2.14 & 16.00 & 14.79 \\
\hline \multirow[t]{2}{*}{-} & M3 & 1.33 & 1.27 & 0.41 & 0.39 & 2.36 & 2.00 & 16.46 & 14.82 \\
\hline & LSD & 0.15 & NS & 0.10 & NS & 0.21 & NS & 1.22 & 1.15 \\
\hline \multirow[t]{4}{*}{0} & MO & 0.82 & 1.04 & 0.24 & 0.21 & 1.85 & 1.64 & 12.40 & 11.97 \\
\hline & M1 & 0.93 & 1.04 & 0.29 & 0.26 & 2.13 & 1.90 & 13.11 & 12.15 \\
\hline & M2 & 1.07 & 1.13 & 0.35 & 0.30 & 2.09 & 1.93 & 13.60 & 12.40 \\
\hline & M3 & 1.11 & 1.12 & 0.31 & 0.30 & 1.97 & 1.80 & 14.09 & 13.50 \\
\hline \multirow[t]{4}{*}{50} & MO & 1.29 & 1.20 & 0.42 & 0.37 & 2.22 & 1.99 & 15.62 & 13.39 \\
\hline & M1 & 1.34 & 1.23 & 0.48 & 0.42 & 2.41 & 2.18 & 15.90 & 14.52 \\
\hline & M2 & 1.47 & 1.32 & 0.56 & 0.49 & 2.44 & 2.10 & 16.14 & 15.75 \\
\hline & M3 & 1.56 & 1.40 & 0.51 & 0.44 & 2.30 & 1.89 & 16.81 & 15.15 \\
\hline \multirow[t]{5}{*}{100} & MO & 1.16 & 1.19 & 0.37 & 0.33 & 2.58 & 2.26 & 16.30 & 14.90 \\
\hline & M1 & 1.16 & 1.18 & 0.40 & 0.38 & 2.96 & 2.47 & 17.15 & 15.37 \\
\hline & M2 & 1.25 & 1.24 & 0.48 & 0.45 & 2.80 & 2.39 & 18.26 & 16.23 \\
\hline & M3 & 1.34 & 1.31 & 0.43 & 0.45 & 2.81 & 2.33 & 18.50 & 15.82 \\
\hline & LSD & 0.26 & 0.32 & 0.17 & NS & 0.36 & 0.42 & 2.11 & 1.99 \\
\hline \multicolumn{10}{|c|}{ Second season } \\
\hline 0 & - & 1.07 & 1.17 & 0.35 & 0.37 & 2.19 & 2.17 & 14.40 & 11.95 \\
\hline 50 & - & 1.48 & 1.37 & 0.55 & 0.56 & 2.49 & 2.48 & 16.08 & 13.39 \\
\hline 100 & - & 1.27 & 1.32 & 0.43 & 0.53 & 2.71 & 3.05 & 16.80 & 15.10 \\
\hline LSD & & 0.20 & 0.13 & 0.15 & NS & 0.34 & 0.42 & 1.06 & 1.24 \\
\hline- & MO & 1.14 & 1.21 & 0.38 & 0.47 & 2.39 & 2.39 & 14.62 & 13.02 \\
\hline- & M1 & 1.24 & 1.27 & 0.43 & 0.50 & 2.54 & 2.71 & 15.38 & 13.47 \\
\hline- & M2 & 1.35 & 1.32 & 0.49 & 0.51 & 2.51 & 2.59 & 16.25 & 13.90 \\
\hline \multirow[t]{2}{*}{-} & M3 & 1.36 & 1.34 & 0.46 & 0.47 & 2.42 & 2.57 & 16.79 & 13.54 \\
\hline & LSD & 0.14 & 0.10 & NS & NS & NS & 0.28 & 1.23 & NS \\
\hline \multirow[t]{4}{*}{0} & MO & 0.95 & 1.12 & 0.30 & 0.35 & 2.15 & 1.94 & 13.45 & 10.94 \\
\hline & M1 & 0.99 & 1.18 & 0.33 & 0.35 & 2.28 & 2.21 & 14.28 & 11.57 \\
\hline & M2 & 1.14 & 1.16 & 0.38 & 0.40 & 2.16 & 2.25 & 14.59 & 12.60 \\
\hline & M3 & 1.20 & 1.22 & 0.39 & 0.41 & 2.17 & 2.30 & 15.30 & 12.71 \\
\hline \multirow[t]{4}{*}{50} & MO & 1.30 & 1.28 & 0.47 & 0.52 & 2.40 & 2.31 & 14.81 & 13.30 \\
\hline & M1 & 1.45 & 1.36 & 0.52 & 0.59 & 2.57 & 2.71 & 15.79 & 13.66 \\
\hline & M2 & 1.60 & 1.43 & 0.61 & 0.59 & 2.59 & 2.52 & 16.60 & 13.61 \\
\hline & M3 & 1.59 & 1.43 & 0.60 & 0.54 & 2.43 & 2.38 & 17.15 & 13.02 \\
\hline \multirow[t]{5}{*}{100} & MO & 1.18 & 1.25 & 0.39 & 0.55 & 2.63 & 2.94 & 15.61 & 14.84 \\
\hline & M1 & 1.30 & 1.29 & 0.44 & 0.58 & 2.77 & 3.23 & 16.09 & 15.20 \\
\hline & M2 & 1.33 & 1.37 & 0.50 & 0.54 & 2.78 & 3.00 & 17.57 & 15.49 \\
\hline & M3 & 1.30 & 1.39 & 0.40 & 0.47 & 2.66 & 3.04 & 17.93 & 14.90 \\
\hline & LSD & 0.25 & 0.17 & NS & NS & NS & 0.48 & 2.13 & 3.15 \\
\hline
\end{tabular}


during the second season which reached its maxima by using M2 level. These increases in constituents may be due to the effect of micronutrients on stimulating biological activities, i.e. enzyme activity, chlorophyll synthesis, rate of translocation of photosynthetic products and increased nutrient uptake through roots after foliar fertilization. Such improvement could be explained by the role of these elements in increasing adsorbing surface of the root and enhance the transportation of the nutrients from the soil to plant organs via the roots. The aforementioned results of micronutrients on chemical constituents are in parallel with those obtained by Gomaa (2008) on Hibiscus sabdariffa and Ajay et al. (2010) on Mentha arvensis L.

Moreover, all combined treatments among foliar micronutrients and BA concentrations induced remarkable increments in $N, P$ and $K$ and total carbohydrate content (\%). Reached its maxima of $N, P$ and $K \%$ in the treatments of $B A$ at $50 \mathrm{mg} / \mathrm{l}+\mathrm{M} 3$ level of micronutrients, $B A$ at $50 \mathrm{mg} / \mathrm{l}+\mathrm{M} 2$ level of micronutrients and $B A$ at $100 \mathrm{mg} / \mathrm{l}+$ M1 level of micronutrients respectively, while the highest content (\%) of total carbohydrate occurred by the application of both combined treatments BA at 100 $\mathrm{mg} / \mathrm{l}+\mathrm{M} 3$ level of micronutrients, BA at $100 \mathrm{mg} / \mathrm{l}+\mathrm{M} 2$ level of micronutrients for $1^{\text {st }}$ and $2^{\text {nd }}$ cuts respectively, during two seasons. Similar results were obtained by Mohamed. (2016) on common bean.

\section{4-Photosynthetic pigments}

Data recorded in Table (5) showed that, photosynthetic pigments, i.e. the content of chlorophyll a, b as well as carotenoids ( $\mathrm{mg} / \mathrm{g}$ of fresh leaves) were progressively affected by spraying BA at different concentrations, where the highest increment in the readings of chlorophyll a, b and carotenoids were observed in all plants treated with BA at high concentration as compared to untreated plants in two cuts during the first and second seasons. These results are in agreement with Talaat and Youssef (1998) and Zayed et al. (1985) on Hibiscus sabdariffa they reported that, using BA increased chlorophyll $a, b$ and carotenoids in the fresh leaves.

A steady increments in all of the above mentioned readings were also found by spraying micronutrients at different levels. A gradual increase in these values as micronutrients increased up to M3 level. The positive effect of micronutrients on the concentrations of leaf pigments may be due to its role in chlorophyll synthesis. In this respect, iron is essential for chlorophyll synthesis in that, it is necessary for the synthesis of $\delta$-aminolevulinic acid and a precursor of chlorophyll (Bogorad, 1966). Iron played a somewhat similar role to $\mathrm{Mg}$ in the porphyrin structure of chlorophyll. Also iron is necessary in the oxidation step from coproporphyrinogen to protoporphyrinogen in chlorophyll synthesis (Machold and Stephan, 1969). With regard to the effect of $\mathrm{Zn}$, Foy et al. (1978) hypothesized that, $\mathrm{Zn}$ interferes with $\mathrm{Fe}$ utilization in the leaves for chlorophyll synthesis. Similar findings were obtained by Ziedan and Eisa (2016) they reported that, the application of $\mathrm{Zn}$ and $\mathrm{Mn}$ increased total chlorophyll content compared with the control.

Treated lemongrass plants with dual application of BA and micronutrients with a variance degree improved chlorophyll a, b as well as carotenoids contents, especially the combined treatment of BA at $100 \mathrm{mg} / \mathrm{l}$ with micronutrients at M3 level the first and second cuts during two seasons as compared to other combinations and the control. 
Table (5): Effect of foliar applications of benzyl adenine (BA) and mixture of micronutrients ( $\mathrm{Fe}, \mathrm{Mn}, \mathrm{Zn}$ and $\mathrm{B}$ ) either individually or in combination on photosynthetic pigments of lemongrass plants in two cuts during both seasons.

\begin{tabular}{|c|c|c|c|c|c|c|c|}
\hline \multicolumn{2}{|c|}{ Treatments } & \multicolumn{2}{|c|}{$\begin{array}{c}\text { Chlorophyll A } \\
\text { (mg/g) }\end{array}$} & \multicolumn{2}{|c|}{$\begin{array}{c}\text { Chlorophyll B } \\
(\mathrm{mg} / \mathrm{g})\end{array}$} & \multicolumn{2}{|c|}{$\begin{array}{l}\text { Carotenoids } \\
(\mathrm{mg} / \mathrm{g})\end{array}$} \\
\hline \multicolumn{8}{|c|}{ First season } \\
\hline BA (mg/l) & Micronutrients & $1^{\text {st cut }}$ & $2^{\text {nd }} c u t$ & $1^{\text {st }}$ cut & $2^{\text {nd }}$ cut & $1^{\text {st }}$ cut & $2^{\text {nd }}$ cut \\
\hline 0 & - & 4.62 & 4.10 & 1.62 & 1.52 & 2.69 & 2.60 \\
\hline 50 & - & 5.75 & 5.26 & 2.58 & 2.05 & 3.60 & 3.02 \\
\hline 100 & - & 6.23 & 5.98 & 3.23 & 3.01 & 4.26 & 3.87 \\
\hline LSD & & 0.59 & 0.42 & 0.98 & 1.05 & 1.12 & 0.57 \\
\hline- & MO & 4.97 & 4.61 & 2.11 & 1.80 & 3.01 & 2.84 \\
\hline - & M1 & 5.51 & 4.99 & 2.35 & 2.23 & 3.42 & 3.12 \\
\hline - & M2 & 5.72 & 5.27 & 2.53 & 2.31 & 3.70 & 3.25 \\
\hline \multirow[t]{2}{*}{-} & M3 & 5.94 & 5.59 & 2.93 & 2.45 & 3.95 & 3.46 \\
\hline & LSD & 0.86 & 0.65 & 0.61 & 0.24 & 0.69 & 0.48 \\
\hline \multirow[t]{4}{*}{$\mathbf{0}$} & MO & 4.13 & 3.74 & 1.39 & 1.28 & 2.43 & 2.30 \\
\hline & M1 & 4.56 & 3.99 & 1.43 & 1.49 & 2.64 & 2.53 \\
\hline & M2 & 4.79 & 4.18 & 1.58 & 1.60 & 2.73 & 2.74 \\
\hline & M3 & 5.03 & 4.51 & 2.11 & 1.74 & 2.98 & 2.86 \\
\hline \multirow[t]{4}{*}{50} & MO & 5.20 & 4.40 & 2.08 & 1.59 & 2.97 & 2.60 \\
\hline & M1 & 5.78 & 5.17 & 2.35 & 2.13 & 3.42 & 2.98 \\
\hline & M2 & 5.94 & 5.60 & 2.71 & 2.20 & 3.86 & 3.12 \\
\hline & M3 & 6.10 & 5.89 & 3.20 & 2.31 & 4.18 & 3.41 \\
\hline \multirow[t]{4}{*}{100} & MO & 5.60 & 5.70 & 2.88 & 2.53 & 3.63 & 3.62 \\
\hline & M1 & 6.19 & 5.82 & 3.27 & 3.07 & 4.20 & 3.85 \\
\hline & M2 & 6.45 & 6.03 & 3.30 & 3.15 & 4.53 & 3.90 \\
\hline & M3 & 6.70 & 6.38 & 3.48 & 3.30 & 4.70 & 4.13 \\
\hline & LSD & 1.51 & 1.12 & 1.06 & 0.42 & 1.19 & 0.83 \\
\hline \multicolumn{8}{|c|}{ Second season } \\
\hline 0 & - & 4.87 & 3.32 & 1.76 & 1.21 & 2.78 & 1.99 \\
\hline 50 & - & 5.33 & 3.93 & 2.04 & 1.62 & 3.12 & 2.74 \\
\hline 100 & - & 5.53 & 4.95 & 2.55 & 2.06 & 3.74 & 3.18 \\
\hline LSD & & 0.35 & 0.94 & 0.62 & 0.42 & 0.73 & 1.02 \\
\hline- & MO & 5.00 & 3.74 & 1.87 & 1.44 & 2.99 & 2.45 \\
\hline - & M1 & 5.12 & 3.90 & 2.02 & 1.52 & 3.16 & 2.54 \\
\hline - & M2 & 5.34 & 4.10 & 2.22 & 1.70 & 3.28 & 2.69 \\
\hline \multirow[t]{2}{*}{-} & M3 & 5.50 & 4.53 & 2.36 & 1.85 & 3.41 & 2.88 \\
\hline & LSD & NS & 0.51 & NS & 0.33 & NS & NS \\
\hline \multirow[t]{4}{*}{0} & M0 & 4.72 & 2.96 & 1.57 & 1.08 & 2.68 & 1.75 \\
\hline & M1 & 4.85 & 3.15 & 1.64 & 1.16 & 2.76 & 1.84 \\
\hline & M2 & 4.79 & 3.34 & 1.88 & 1.24 & 2.80 & 2.11 \\
\hline & M3 & 5.12 & 3.86 & 1.97 & 1.38 & 2.88 & 2.29 \\
\hline \multirow[t]{4}{*}{50} & M0 & 4.93 & 3.50 & 1.73 & 1.40 & 2.69 & 2.58 \\
\hline & M1 & 5.23 & 3.61 & 1.90 & 1.48 & 3.14 & 2.67 \\
\hline & M2 & 5.61 & 4.11 & 2.16 & 1.72 & 3.25 & 2.77 \\
\hline & M3 & 5.58 & 4.52 & 2.40 & 1.89 & 3.40 & 2.95 \\
\hline \multirow[t]{5}{*}{100} & MO & 5.37 & 4.77 & 2.31 & 1.85 & 3.60 & 3.02 \\
\hline & M1 & 5.30 & 4.95 & 2.52 & 1.94 & 3.59 & 3.12 \\
\hline & M2 & 5.64 & 4.86 & 2.64 & 2.15 & 3.81 & 3.21 \\
\hline & M3 & 5.81 & 5.22 & 2.73 & 2.30 & 3.96 & 3.40 \\
\hline & LSD & 0.85 & 0.88 & 0.92 & 0.57 & 1.12 & 1.23 \\
\hline
\end{tabular}




\section{5-Essential oil composition}

Gas liquid-Mass spectrum analyses Table (6) showed that, the identified compounds were 10 for essential oil of Cymbopogon citratus. Citral a (geranial) was found to be the first major compound in the essential oil of Cymbopogon citratus and ranged from 36.84 to $44.63 \%$. Its minimum content was observed from plants treated by zero
BA + M3 level of micronutrients while, the maximum content was recorded with plants that received $B A$ at $100 \mathrm{mg} / \mathrm{l}+\mathrm{M} 1$ level of micronutrients. The second main compound was identified as citral b (neral) which ranged from its minimum content $(29.25 \%)$ by using zero BA + M3 level of micronutrients to its maximum relative percent $(36.44 \%)$ by using $B A$ at $50 \mathrm{mg} / \mathrm{l}+$ M2 level of micronutrients.

Table (6): Effect of foliar applications of benzyl adenine (BA) and mixture of micronutrients ( $\mathrm{Fe}, \mathrm{Mn}, \mathrm{Zn}$ and $\mathrm{B}$ ) either individually or in combination on essential oil composition of lemongrass plants in $2^{\text {nd }}$ cut during the first season.

\begin{tabular}{|c|c|c|c|c|c|c|c|c|c|c|c|}
\hline $\begin{array}{c}\mathrm{BA} \\
(\mathrm{mg} / \mathrm{l})\end{array}$ & Micronutrients & $\begin{array}{c}\alpha- \\
\text { Pinene }\end{array}$ & $\begin{array}{c}1-8 \\
\text { cineole }\end{array}$ & $\begin{array}{l}\text { Geranyl } \\
\text { acetate }\end{array}$ & Geraniol & Terpinolene & Linalool & Limonene & myrcene & $\begin{array}{l}\text { Citral B } \\
\text { (Neral) }\end{array}$ & $\begin{array}{c}\text { Citral A } \\
\text { (Geranial) }\end{array}$ \\
\hline 0 & - & 0.66 & 0.78 & 0.71 & 1.21 & 1.26 & 3.95 & 7.40 & 12.02 & 30.58 & 38.72 \\
\hline 50 & - & 1.01 & 0.77 & 0.68 & 1.25 & 1.40 & 2.61 & 5.00 & 10.17 & 34.42 & 40.90 \\
\hline 100 & - & 1.00 & 0.86 & 0.94 & 1.05 & 2.28 & 2.77 & 3.98 & 9.21 & 31.94 & 43.19 \\
\hline- & MO & 1.13 & 0.93 & 1.04 & 1.57 & 1.60 & 3.68 & 5.34 & 10.32 & 32.03 & 39.51 \\
\hline- & M1 & 0.68 & 0.63 & 0.46 & 0.90 & 1.50 & 2.85 & 5.51 & 10.75 & 33.75 & 41.30 \\
\hline- & M2 & 0.60 & 0.71 & 0.78 & 0.62 & 1.60 & 2.38 & 5.54 & 10.49 & 32.84 & 41.95 \\
\hline- & M3 & 1.15 & 0.94 & 1.16 & 1.58 & 1.88 & 3.54 & 5.45 & 10.31 & 30.64 & 41.00 \\
\hline \multirow[t]{4}{*}{0} & MO & 0.45 & 0.55 & 0.63 & 1.20 & 1.50 & 4.52 & 6.74 & 11.93 & 30.15 & 38.76 \\
\hline & M1 & 0.58 & 0.75 & 0.70 & 1.36 & 1.49 & 3.50 & 6.82 & 12.35 & 31.40 & 39.16 \\
\hline & M2 & 0.71 & 0.84 & 0.71 & 0.70 & 0.64 & 2.62 & 7.90 & 12.01 & 31.52 & 40.15 \\
\hline & M3 & 0.92 & 0.98 & 0.80 & 1.58 & 1.41 & 5.18 & 8.15 & 11.82 & 29.25 & 36.84 \\
\hline \multirow[t]{4}{*}{50} & MO & 1.04 & 1.01 & 0.95 & 1.79 & 1.63 & 3.08 & 5.12 & 10.36 & 33.82 & 39.60 \\
\hline & M1 & 1.13 & 0.77 & 0.41 & 0.84 & 1.12 & 2.43 & 5.33 & 10.80 & 35.63 & 40.11 \\
\hline & M2 & 0.23 & 0.35 & 1.14 & 0.27 & 1.48 & 2.01 & 4.95 & 9.81 & 36.44 & 41.52 \\
\hline & M3 & 1.65 & 0.98 & 1.22 & 2.11 & 1.37 & 2.95 & 4.60 & 9.71 & 31.79 & 42.37 \\
\hline \multirow[t]{4}{*}{100} & MO & 1.91 & 1.25 & 1.54 & 1.74 & 1.68 & 3.46 & 4.17 & 8.69 & 32.12 & 40.18 \\
\hline & M1 & 0.33 & 0.39 & 0.27 & 0.51 & 1.89 & 2.63 & 4.40 & 9.11 & 34.22 & 44.63 \\
\hline & M2 & 0.88 & 0.96 & 0.49 & 0.90 & 2.70 & 2.53 & 3.78 & 9.66 & 30.56 & 44.18 \\
\hline & M3 & 0.90 & 0.87 & 1.46 & 1.05 & 2.88 & 2.49 & 3.60 & 9.41 & 30.88 & 43.79 \\
\hline
\end{tabular}


The quality of $\boldsymbol{C}$. citratus essential oil was related to its citral content which considered a mixture between neral and geranial with concentration range from 65 to 75\% (Combrincket al., 2011). Myrcene was identified as the third main constituent and ranged from 8.69 to $12.35 \%$. Limonene was found to be the $4^{\text {th }}$ main compound $(3.60-8.15 \%)$ followed by linalool $(2.01-5.18 \%)$. These results agreed with Aziz and El-Ashry (2002); Koffi1 et al. (2009) and Aziz et al. (2010), they reported that, the main components of $C$. citratusoil are neral, geranial and citronellol which represented about $80 \%$ of the essential oil.

\section{REFERENCES}

Abd El-Aziz, N.G. (2007). Stimulatory effect of NPK fertilizer and benzyladenine on growth and chemical constituents of Codiaeum variegatum L. plant. AmericanEurasian J.Agric. and Environ. Sci., 2(6): 711-719.

Abdullah, A.A., J. Grace and M.M. Yeoman (1986). Rapid micropropagation of Calabrian pine from primary and secondary buds on shoot explants. Can. J. Forest Res., 16: 637-641.

Ajay, K., H.K. Patro and K. Walanand (2010). Effect of zinc and sulphur on herb, oil yield and quality of Menthol mint (Mentha arvensis L.) var. Kosi. J. Chem. Pharm. Res., 2(4):642-648.

Aziz, E. E. and S.M. El-Ashry (2002). The influence of slow release and conventional nitrogen fertilizers on plant growth and chemical constituents of Cymbopogon citratus L. grown in sandy soil. J. Agric. Sci. Mansoura Univ., 27(5): 3333-3346.

Aziz, E. E., A. A. Ezz El-Din and E.A. Omer (2010). Influence of zinc and iron on plant growth and chemical constituents of Cymbopogon citratus
L. grown in newly reclaimed land. Inter. J. of Acad. Res., 2(4): 278-283.

Barbara, F.R. and L.J. Brain (1994). Minitab Hand Book. Duxbury Press. An Imprint of Wad Sworth Publish. Comp., Belonont, California.

Bogorad, L. (1966). The Biosynthesis of Chlorophylls. In The Chlorophylls. Vernon, L.P. and Seely, G.R., Eds., Academic Press, New York, pp. 481510.

British, P. (1963). Determination of Volatile Oil in Drugs. The Pharmaceutical Press 17 Bloomsburg, square. W.C.I. London.

Brown, P.H., N. Bellaloui, M.A. Wimmer, E.S. Bassil, J. Ruiz, H. Hu, H. Pfeffer, F. Dannel and V. Romheld (2002). Boron in Plant Biology. Plant Biol., 4:205-223.

Cakmak, I. (2008). Enrichment of cereal grains with zinc: agronomic or genetic bio-fortification? Plant Soil, 302:1-17.

Carlson, L.H.C.; Machado, R.A.F.; Spricigo, C.B.; Pereira L.K. and A. Bolzan (2001). Extraction of lemongrass essential oil with dense carbon dioxide. Journal of Supercritical Fluids, 21: 33-39.

Chao, S. and D. Young (2000). Screening for inhibitory activity of essential oils on selected bacteria, fungi and viruses. J. Essent. Oil Res., 12: 639649.

Chapman, H.D. and P.F. Pratt (1982). Methods of Plant Analysis. I. Methods of Anaylsis for Soil, Plant and Water. Chapman Publishers, Riverside, California, USA.

Combrinck, S., T. Regnier and G.P.P. Kamatou (2011). In vitro activity of eighteen essential oils and some major components against common postharvest fungal pathogens of fruit. Industrial Crops and Products, 33(2):344-349. 
Cottenie, A., M. Verloo, L. Kiekens, G. Velghe and R. Camerlynck (1982). Chemical Analysis of Plants and Soils. Lab. Analytical and Agrochem, State Univ., Ghent-Belgium.

Davies, P.J. (1995). Plant Hormones: Physiology, Biochemistry and Molecular Biology. Kluwer Academic Publishers, Dordrecht, The Netherlands., pp.833.

Dhakal, M.R. and L. Erdei (1986). Long term effects of plant hormones on $\mathrm{K}+$ levels and transport in young wheat plants of different $\mathrm{K}^{+}$status. Physiol. Plant, 68: 632-636.

Dorman, H.J., S. Peter and S.G. Deans (2000). In vitro antioxidant activity of a number of plant essential oils and phytoconstituents. J. Essent. Oil Res., 12: 241-248.

Dubois, M., K.A. Gilles, J.K. Hamilton, P.A. Robers and F. Smith (1956). Calorimetric method for determination of sugars and related substance.Anal. Chem. 28; 350-356.

Duszka, K., B.F.C. Clark, F. Massino and J. Barciszewski (2009). Biological Activities of Kinetin. In: Ramawat K.G. (Eds.) Herbal Drugs: Ethnomedicine to Modern Medicine. Verlag Berlin Heidelberg, Berlin, pp: 369- 380.

Eid, R.A. and B.H. Abou-Leila (2006). Response of croton plants to gibberellic acid, benzyl adenine and ascorbic acid application. World $\mathbf{J}$. Agric. Sci., 2:174-179.

Eid, R.A., R.Kh.M. Khalifa and S.H.A. Shaaban (2010). Effect of foliar application of zinc and benzyladenine on growth, yield and chemical constituents of tuberose plants. Res. J. Agric. and Biol. Sci., 6(6):732-743.

El-Quesni, F.E.M., S. L. Taha, M.M.S. Ibrahim and M.M. Farahat (2007). Growth and chemical constituents of Cupressus sempervirens L. plant as influenced by kinetin and iron treatments at Nubaria. American
Eurasian J.Agric. \& Environ. Sci., 2(3): 282-288.

Eraki, M.A. (1994). Effect of benzyladenine (BA) application on the growth, fruit yield and some chemical constituents of Hibiscus sabdarifa $L$. plants. MinofiyaJ.Agric.Res., 2:623637.

Fahad, S., A. Masood, M. Anjum and S. Hussain (2014). The effect of micronutrients ( $B, \mathrm{Zn}$ and $\mathrm{Fe}$ ) foliar application on the growth, flowering and corm production of gladiolus (Gladiolus grandiflorus L.) in Calcareous Soils. J. Agr. Sci. Tech., 16: 1671-1682.

Foy, C.D., R.L. Chaney and M.C White (1978). The physiology of metal toxicity in plants. Annu. Rev. Plant Physiol., 29: 511-566.

Ghanta, P.K. and S.K. Mitra (1993). Effect of micronutrients on growth, flowering, leaf nutrient content and yield of banana cv., Giant cavandishii. Crop Research, 2: 284-287.

Gomaa, A.O. (2008). Effect of tryptophan, $\mathrm{Fe}, \mathrm{Zn}$, and Mn foliar application on growth, productivity and chemical composition of roselle plants. J. Biol. Chem.Environ.Sci., 3(1): 771-790.

Gomaa, M.A., H.A. Zeid and F.I. El-Araby (1986). The effect of spraying with some micronutrient elements on growth and yield of broad bean (Vicia faba L.). Ann. Agric. Sci., Moshtohor, 24(2): 657-665.

Heidarian, A.R., H. Kord, K. Mostafavi, A.P. Lak and F.A. Mashhadi (2011). Investigating $\mathrm{Fe}$ and $\mathrm{Zn}$ foliar application on yield and its components of soybean (Glycine max L. Merr.) at different growth stages. J. Agric. Biotechnol. Sustain. Dev., 3(9): $189-197$.

Horne, D., M. Holm and C. Oberg (2001). Antimicrobial effects of essential oils on Streptococcus pneumoniae. J. Essent. Oil Res., 13: 387-392. 
Hrotko, K., L. Magyar and T. Buban (1996). Improved feathering by benzyladenine application on one years old 'Idared' apple trees in the nursery. J. Hort. Sci., 28(3-4): 49-53.

Khosa, S. S., A. Younis, A. Rayit, S. Yasmeen and A. Riaz (2011). Effect of foliar application of macro and micronutrients on growth and flowering of Gerbera jamesonii L. Amer. Euras. J. Agric. Environ. Sci., 11: 736-757.

Kim, H. T. (1996). "Soil Sampling, Preparation and Analysis". Marcel DekkerInc., New York, p. 391.

Koffil, K., S. Komla1, G. Catherine, R. Christine, J. Pierre and N. Laurence (2009). In vitro cytotoxic activity of Cymbopogon citratus L. and Cymbopogon nardus $L$. essential oils from Togo Bangladesh. J. Pharmacol., 4:29-34.

Krishnamoorthy, H.N. (1981). Plant Growth Substances. MC. Grow. Hill Publishing Company Ltd., New Delhi.

Letham, D.S. (1969). Cytokinins and their relations to other phytohormones. Bio-Sciences, 19: 309-316.

Machold, O. and U. W. Stephan (1969). The function of iron in porphyrin and chlorophyll biosynthesis. Phytochemistry, 8: 2189-2192.

Malakouti, M.J. (2008). The effect of micronutrients in ensuring efficient use of macronutrients. Tur. J. Agric.For., 32: 215-220.

Mazrou, M.M. (1992). The growth and tropan alkaloids distribution on the different organs of Datura innoxia Mill. plants in relation to benzyladenine (BA) application. MinofiyaJ.Agric.Res., 17:1971-1983.

Merillon, J.M., P. Dupeon, M. Montagu, D. Liu, J.C. Chenieux and M. Rideau (1993). Modulation by cytokinin of membrane lipids in Catharanthus roseus cells. Plant Physiol. Biochem., 31.
Millaleo, R., M. Reyes-Diaz, A.G. Ivanov, M.L. Mora and M. Alberdi (2010). Manganese as essential and toxic element for plants: transport, accumulation and resistance mechanisms. J. Soil Sci. Plant Nutr., 10(4): 470-481.

Mohamed, M.H.M. (2016). Effect of some growth regulators in the presence of boron on growth, yield and chemical composition of common bean under different sowing dates. J. Plant Production, Mansoura Univ., 7(6): 537 $-543$

Mok, D.W.S. and M.C. Mok (2001). Cytokinin metabolism and action. Annu. Rev. Plant Physiol. Plant Mol. Biol., 52: 89-118.

Mousavi, S., M. Shahsavari and M. Rezaei (2011). A general overview on manganese $(\mathrm{Mn})$ importance for crops production. Aust. J. Basic Appl Sci., 5(9): 1799-1803.

Nasiri, Y., S. Zehtab-Salmasi, S. Nasrullahzadeh, N. Najafi and K. Ghassemi-Golezani (2010). Effects of foliar application of micronutrients (Fe and $\mathrm{Zn}$ ) on flower yield and essential oil of chamomile (Matricaria chamomilla L.). Journal of Medicinal Plants Research, 4(17): 1733-1737.

Negrelle, R.R.B. and E.C. Gomes (2007). Cymbopogon citratus (D.C.) Stapf.: chemical composition and biological activities. Rev. Bras. PI. Med., 9: 80-92.

Nijjar, G.S. (1985). Nutrition of Fruit Trees. Kalyani Publishers New Delhi, pp: 50-100, India.

Onawunmi, G.O., W.A. Yisak and E.O. Oqunlana (1984). Antibacterial constituents in the essential oil of Cymbopogon citratus (DC.) Stapf. J. Ethnopharmacol., 12(3): 279-286.

Page, A. L., R. H. Miller and D. R. Keeney (1982). "Methods of Soil Analysis". II. Chemical and Microbiogical Properties. 2nd Ed. Madison, Wisconsin, U. S. A. 
Paviani, L., S.B.C. Pergher and C. Dariva (2006). Application of molecular sieves in the fractionation of lemongrass oil from high-pressure carbon dioxide extraction. Brazilian Journal of Chemical Engineering, 23: 219-225.

Ravi, S., H.T. Channal, N.S. Hebsur, B.N. Patil and P.R. Dharmatti (2008). Effect of sulphur, zinc and iron nutrition on growth, yield, nutrient uptake and quality of safflower (Carthamus tinctorius L.). Karnataka J. Agric. Sci., 21: 382-385.

Sorokin, H. and K.V. Thimann (1964). The histological basis for inhibition of axillary buds in Pisum sativum and the effects of auxins and kinetin on xylem development. Protoplasma, 59:326 - 350 .

Talaat, I.M. and A.A. Youssef (1998). Response of roselle plants (Hibiscus sabdariffa L.) to some growth regulating substance. Egypt, J. Physiol. Sci., 22:327-338.

Van-Steveninck, R.F. (1976). Effect of Hormones and Related Substances on Iron Transport. In Lüttge, $U$. and Pitman, M. G. (Eds.): Transport in Plants IIB.-Springer Verlag, Berlin, pp: 307-328.

Vodanik, D., G. Jentschke, E. Fritz, N. Gogala and D.I. Godbold (1999). Root applied cytokinin reduces lead uptake and effects its distribution in Norway spruce seedlings. Physiol. Plant, 160: 75-81.

Witham, F. H., D. F. Blaydes and R. M. Devlin (1971). Experiments in Plant
Physiology. Van Nostr and Reinhold Co., New York. pp. 55-58.

Yadegari, M. (2015). Foliar application of micronutrients on essential oils of borago, thyme and marigold. Journal of Soil Science and Plant Nutrition,15 (4): 949-964.

Yari, L., S.A.M. Modarres-Sanavy and A. Soroushzadeh (2004). Effect of foliar application of zinc and manganese on quality traits of five safflower cultivars. Iranian J. Soil Water Sci., 18: 214-218.

Younis, A., A. Riaz, M. Sajid, N. Mushtaq, M. Ahsan and M. Nadeem (2013). Foliar application of macro- and micronutrients on the yield and quality of Rosa hybrid cvs. Cardinal and Whisky Mac. African Journal of Biotechnology, 12(7): 702-708.

Youssef, A.A., H. M. Mahgoub and M. I. Talaat (2004). Physiological and Biochemical and aspects of Matthiola incana L. plants under the effect of puterscine and kinetin treatments. Egypt J. Appl. Sci., 19(9): 492-510.

Zayed, E.A., E. Nofal and M. El-Afry (1985). Effect of benzyladanine (BA) on different strains of roselle plants (Hibiscus sabdariffa L.) 1- Effect on growth characters and yield. J. Agric. Sci. Mansoura University, 10:154-159.

Ziedan, El.H. and E.A. Eisa (2016). The use of some micronutrients and plant extracts of resistance to powdery mildew and nutrition dill plants in the Gharbiyah governorate. J. Plant Prot. and Path., Mansoura Univ., 7 (9): 579 586. 


\title{
تأثير الإضافات الورقية لمنشطات النمو المختلفة علي نمو و إنتاجية حشيشة الليمون
}

\author{
محمد محمد موسي \\ قسم البساتين - كلية الزراعة - جامعة المنوفية- شبين الكوم -مصر موليد
}

الملخص العربي

أُجريت تجربة خلال موسمي نمو متتاليين (2013 و 2014 م) بالمزرعة البحثية بكلية الزراعة - جامعة المنوفية -

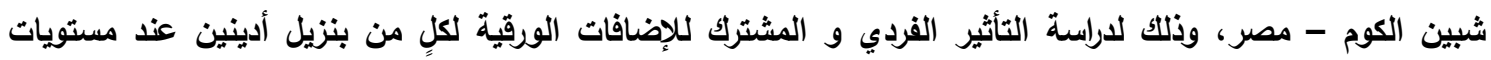
مختلفة ( صفر، 50 و 100 ملليجرام / لتر ) مع خليط من المغذيات الصغري ( الحديد، المنجنيز، الزتك و البورون)

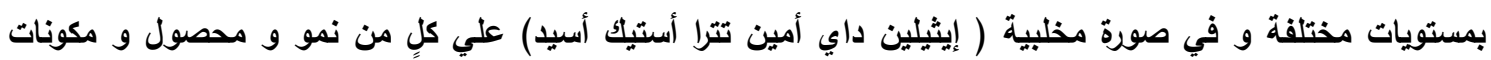
نباتات حشيثة الليمون النامية في أرض طينية. تم إضافة المغذيات الصغري رشاً و بتركيزات مختلفة كالآتي:- مصفر

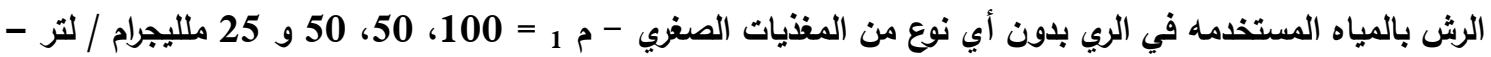

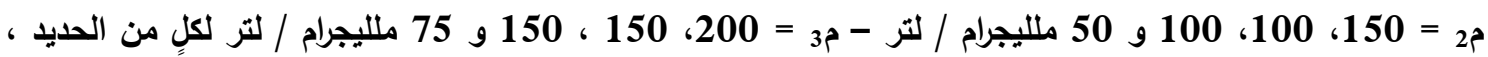
المنجنيز ، الزتك و البورون علي التوالي ـ وقد صُممت التجرية في تصميم قطع منثقة بثُلاث مكررات.

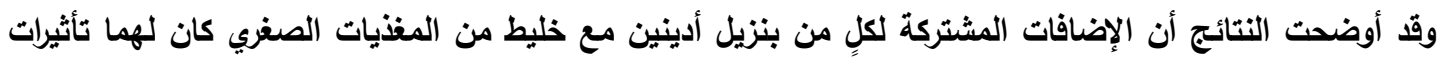

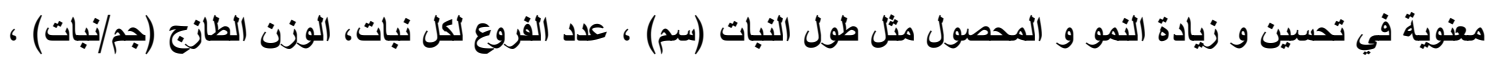

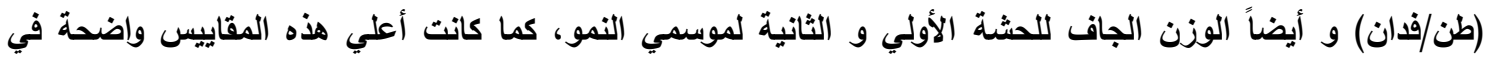

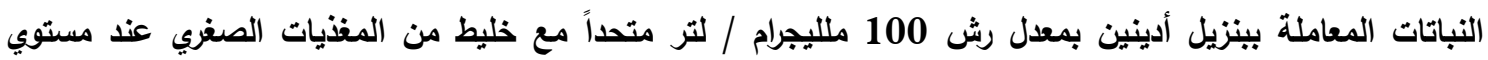

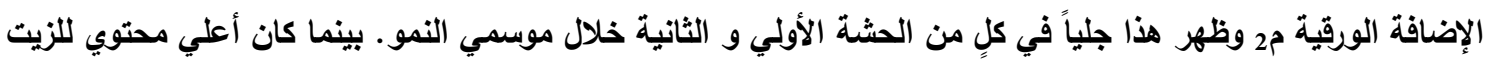

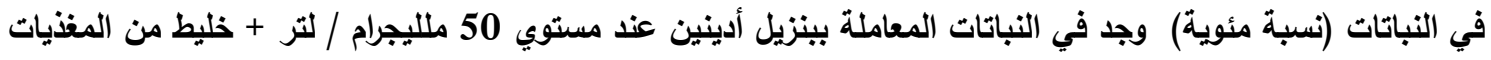

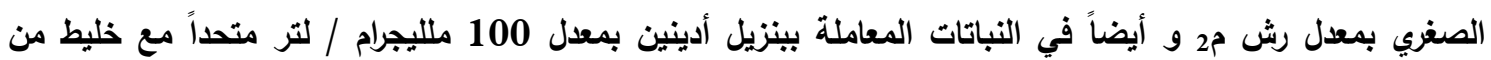

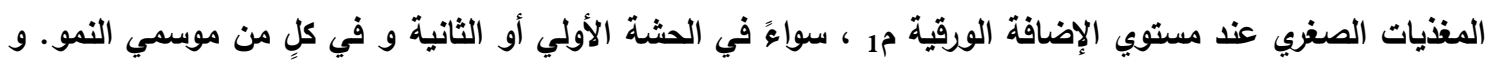

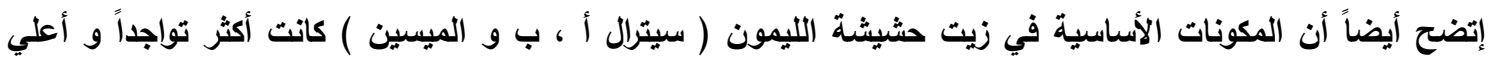

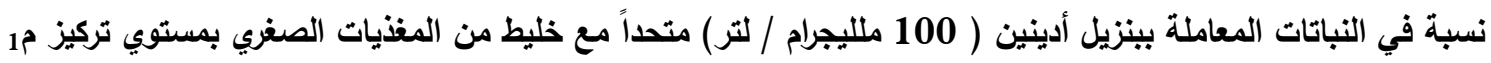

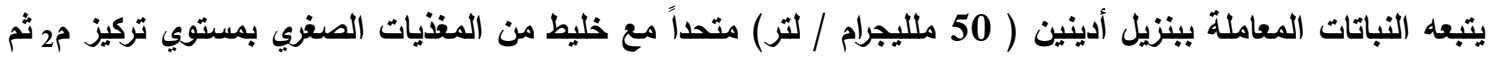
النباتات المعاملة بخليط من المغنيات الصغري بمستوي تركيز م1 ويدون إضافة لبنزيل أدينين ، علي التوالي وذلك في التئي الحشة الثانية من الموسم الثاني.

\footnotetext{
أسماء السادة المحكمين

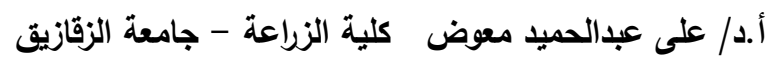
أ.د/ مجدى رابح محمد رابح كلية الزراعة - جامعة المنوفية الزئة
} 
Growth behavior and productivity of lemongrass (cymbopogon citratus) ........ 